\title{
Leguminosae in an altitudinal gradient in the Atlantic Forest of Serra do Mar State Park, São Paulo, Brazil
}

\author{
Edson Dias da Silva ${ }^{1,3}$, Ana Maria Goulart de Azevedo Tozzi ${ }^{1}$ \& Leonardo Dias Meireles ${ }^{2}$ \\ ${ }^{1}$ Universidade Estadual de Campinas, Instituto de Biologia, Departamento de Biologia Vegetal, Campinas, \\ SP, Brazil. \\ ${ }^{2}$ Universidade de São Paulo, São Paulo, SP, Brazil. \\ ${ }^{3}$ Corresponding author: Edson Silva, e-mail: edsonxv@gmail.com
}

SILVA, E.D., TOZZI, A.M.G.A., MEIRELES, L.D. Leguminosae in an altitudinal gradient in the Atlantic Forest of Serra do Mar State Park, São Paulo, Brazil. Biota Neotropica. 16(1): e20140130. http://dx.doi.org/10.1590/1676-0611-BN-2014-0130

\begin{abstract}
Studies on floristic and structural variations of forests in relation to altitude have contributed to the knowledge of patterns and causes of spatial distribution of plants in the Atlantic Forest. Geographical variables such as latitude, longitude and altitude result in different vegetation types, which limits newly established are not consensus. In the north coast of São Paulo state altitudes vary from the Restinga Forest, near the sea level, to the vegetation at the top of Cuscuzeiro Mountain at 1,279 $\mathrm{m}$ altitude. In order to evaluate the richness, taxonomic diversity, floristic similarity and the potential indicator of Leguminosae in the characterization of different vegetation types of Atlantic Forest on the northern coast of São Paulo, a matrix with the presence and absence of 142 species, in 15 different altitudinal belts was built. The greatest species richness was observed in the Restinga Forest $(0-10 \mathrm{~m})$, with 84 species, and in Montane Forest $(500-1,200 \mathrm{~m})$, with 69 species. The altitudinal belt with the highest number of tree species was $10-50 \mathrm{~m}$, with 34 species. In the higher altitudes that number was significantly lower with six species of 1,100-1,200 m, and no species above this quota. The cluster analysis (Jaccard index) showed dissimilarity of the belts $0-10 \mathrm{~m}$ and 1,100-1,200 $\mathrm{m}$ in relation to the intermediate belts. The Lowland Forest and Submontane share the largest number of species (25). Some species characterize certain formations or have their preferred environment located at a specific elevation, as is the case of Abarema brachystachya and Inga subnuda (0-20 m), Inga lanceifolia, Inga mendoncaei and Ormosia minor (800-1,200 m). Distinguished for occupying all the phytophysiognomies: Abarema langsdorffii and Senna macranthera. Leguminosae, although well adapted to the first colonization and exploration of diverse environment, was poorly represented above 1,100 m altitude.
\end{abstract}

Keywords: Ombrophilous Dense Forest, Fabaceae, phytophysiognomies, vegetation types.

SILVA, E.D., TOZZI, A.M.G.A., MEIRELES, L.D. Leguminosae em um gradiente altitudinal na Floresta Atlântica do Parque Estadual da Serra do Mar, São Paulo, Brasil. Biota Neotropica. 16(1): e20140130. http://dx.doi.org/10.1590/1676-0611-BN-2014-0130

Resumo: Estudos sobre variações florísticas e estruturais da floresta em relação à altitude têm contribuído para o conhecimento dos padrões e causas da distribuição espacial de plantas na Floresta Atlântica. Variáveis geográficas como latitude, longitude e altitude resultam em diferentes fitofisionomias, cujos limites recentemente estabelecidos não são um consenso. No litoral norte do estado de São Paulo as altitudes variam desde a Floresta de Restinga, próximo ao nível do mar, até a vegetação do topo do morro do Cuscuzeiro a $1.279 \mathrm{~m}$ de altitude. Para avaliar a riqueza, a diversidade taxonômica, similaridade florística e o potencial indicador de Leguminosae na caracterização das diferentes fitofisionomias da Floresta Ombrófila Densa no litoral norte de São Paulo foi construída uma matriz com a presença e ausência de 142 espécies em 15 diferentes faixas altitudinais. A maior riqueza de espécies foi observada na Floresta de Restinga (0-10 m), com 84 espécies, e na Floresta Montana (500$1.200 \mathrm{~m}$ ), com 69 espécies. A faixa altitudinal com maior número de espécies arbóreas foi a de 10-50 m, com 34 espécies. Nas maiores altitudes esse número foi expressivamente menor, seis espécies de 1.100$1.200 \mathrm{~m}$ e nenhuma acima dessa cota. A análise de agrupamento (índice de Jaccard) revelou dissimilaridade das faixas 0-10 m e 1.100-1.200 m em relação às faixas intermediárias. A Floresta de Terras baixas e a Submontana compartilham o maior número de espécies (25). Algumas espécies caracterizam certas formações ou têm o seu ambiente preferencial localizado em uma altitude específica, como é o caso de Abarema brachystachya e Inga subnuda (0-20 m), Inga lanceifolia, Inga mendoncaei e Ormosia minor (800-1.200 m). Destacam-se por ocupar todas as fitofisionomias: Abarema langsdorffii e 
Silva, E.D. et al

Senna macranthera. Leguminosae, embora bem adaptada à primeira colonização e exploração de diversos ambientes, está pobremente representada acima de $1.100 \mathrm{~m}$ de altitude.

Palavras-chave: Floresta Ombrófila Densa, Fabaceae, fitofisionomias, tipos de vegetação.

\section{Introduction}

The Atlantic Forest, the second largest rain forest in South America and one of the world's richest in biodiversity and endemism (Mori et al. 1981, Joly et al. 1999, Myers et al. 2000), is located along the Brazilian coast occupying approximately $16,377,472$ ha or $11.7 \%$ of its original formation, which was 150 million hectares (Ribeiro et al. 2009). Most continuous remnants of Atlantic Forest are located primarily in the state of São Paulo and Paraná coast in southeastern Brazil. In São Paulo, where there is only $5 \%$ of native forests with little anthropic action, the mountainous regions stand out, especially the facade of the Serra do Mar (Kronka et al. 2003). The Serra do Mar is a set of festooned scarps with about $1,000 \mathrm{~km}$ stretching from Rio de Janeiro to the north of Santa Catarina, where it ceases to exist as an orographic unit of scaped rim plateau and falls apart in strands of parallel mountain ranges and isolated mountains drained directly into the sea, especially by the basin of Itajaí River (Almeida \& Carneiro, 1998). The flora of the Atlantic Forest have been inventoried and patterns of richness and diversity described and interpreted, especially at the level of communities. Distribution patterns of the most representative families, however, have been little explored.

The Leguminosae (or Fabaceae) is the second largest family of eudicotyledons and is comprised of approximately 727 genera and 19,327 species (Lewis et al. 2005). It presents a wide geographical distribution and is characterized by high species richness in various vegetation types in different regions of the world, from peaks of high mountains to the sandy coastline, tropical rainforest to deserts. There are even aquatic species (Lewis 1987). In Brazil about 212 genera and 2,722 species (Lima et al. 2012) were cataloged, which occurrence is very significant in most vegetation types, especially the Atlantic Forest, where the family has high representation among the elements of the tree layer (Lima 2000). Recent estimates of Lima et al. (2009) lists 945 species of Leguminosae for the Atlantic Forest, and 391 would be unique to that phytogeographic domain.

Floristic inventories and phytosociological studies conducted in various regions of the Atlantic Forest from Bahia to Paraná (Mantovani 1991, Marques et al. 1997, Silva 1998, Assis 1999, Tabarelli \& Mantovani 1999, Oliveira Filho \& Fontes 2000, Pereira \& Assis 2000, Scudeller et al. 2001, Lacerda 2001, Borém \& Oliveira-Filho 2002, Mamede et al. 2004, Peixoto et al. 2005, Schmidlin 2005, Amorim et al. 2009, Meireles 2009, Assis et al. 2011) are already providing evidence of the importance of the Leguminosae family in the composition and structure of this forest. For the Atlantic Forest of São Paulo, however, where there is an expressive representativity of the family, floristic surveys in different remaining areas are scarce, especially surveys on the Caesalpinioideae and Mimosoideae subfamilies.

Analysis of plant diversity in tropical forest altitudinal gradients (Richards 1996, Gentry 1988, Kitayama 1992, Vasquez \& Givnish 1998) suggest that the main trend observed with increasing altitude is the decrease in number of species, mostly trees. Rich families in trees as Leguminosae, Sapotaceae,
Myristicaceae, Meliaceae, Sapindaceae, Burseraceae and Chrysobalanaceae are poorly represented in neotropical montane forests (Gentry 1988). Factors such as altitude and topography create different microsites, causing heterogeneous distribution of species and structural differences in communities (Whitmore 1984). In most studies in gradients this heterogeneity is associated with precipitation levels, soil physicochemical characteristics, differences in temperature, changes in air humidity, wind speed, fog and luminosity.

Research on floristic and structural changes in arboreal vegetation in relation to elevation performed in the Atlantic Forest (Rodrigues \& Shepherd 1992, Roderjan 1994, Lacerda 2001, Custódio Filho 2002, Blum \& Roderjan 2007, Bertoncello 2009) have contributed to the knowledge of patterns and causes of spatial variability of plants in Brazilian forests. However, there is not sufficient information on how the main families of angiosperms are distributed in relation to altitude.

Studies conducted in altitudinal gradients in Serra do Mar (Roderjan 1994, Lacerda 2001, Custódio Filho 2002, Bertoncello 2009) have shown that species richness decreases at higher altitudes, however, due to the small number of studies and differences among methods of analysis and sampling area, these issues are not fully understood yet.

The main objectives of this study were to investigate: which altitudinal zones present higher riches for the species of Leguminosae; if the genera, tribes or subfamilies of Leguminosae are equally distributed along the gradient or if there is an evident differentiation within these groups; what is the altitudinal amplitude of each species along the found phytophysiognomies; if there are species that could be indicators of local vegetation formations in this part of Serra do Mar; if substitution of species occurs along the gradient; what are the altitudinal zones with higher floristic similarity within the studied range.

\section{Material and methods}

The study area is located in the northeastern region of São Paulo state, in Picinguaba and Santa Virgínia Nucleus, Serra do Mar State Park (Figure 1). The Picinguaba Nucleus is located in Ubatuba and Santa Virgínia Nucleus covers the municipalities of São Luis do Paraitinga $(70 \%)$, Cunha $(20 \%)$ and Ubatuba (10\%).

In the Picinguaba Nucleus three areas of study were utilized. The first is located near the headquarters of the Nucleus, in the single portion of the Serra do Mar State Park that reaches the coastline, where we can find the Restinga Forest. Restinga, considering here the botanical (Rizzini 1997, Assis et al. 2004) and geomorphological (Suguio \& Tessler 1984) concepts, is a vegetation complex with strong marine influence which develops in Quaternary sandy sediments resulting from variations in sea level that occurred during the Holocene. The second, is located to the west of the headquarter of the Nucleus where the Ombrophilous Dense Forest prevails (according to Veloso et al. 1991, recently updated et IBGE 2012). The third is located near the central-south headquarter in the city of Ubatuba where the Ombrophilous Dense Forest 


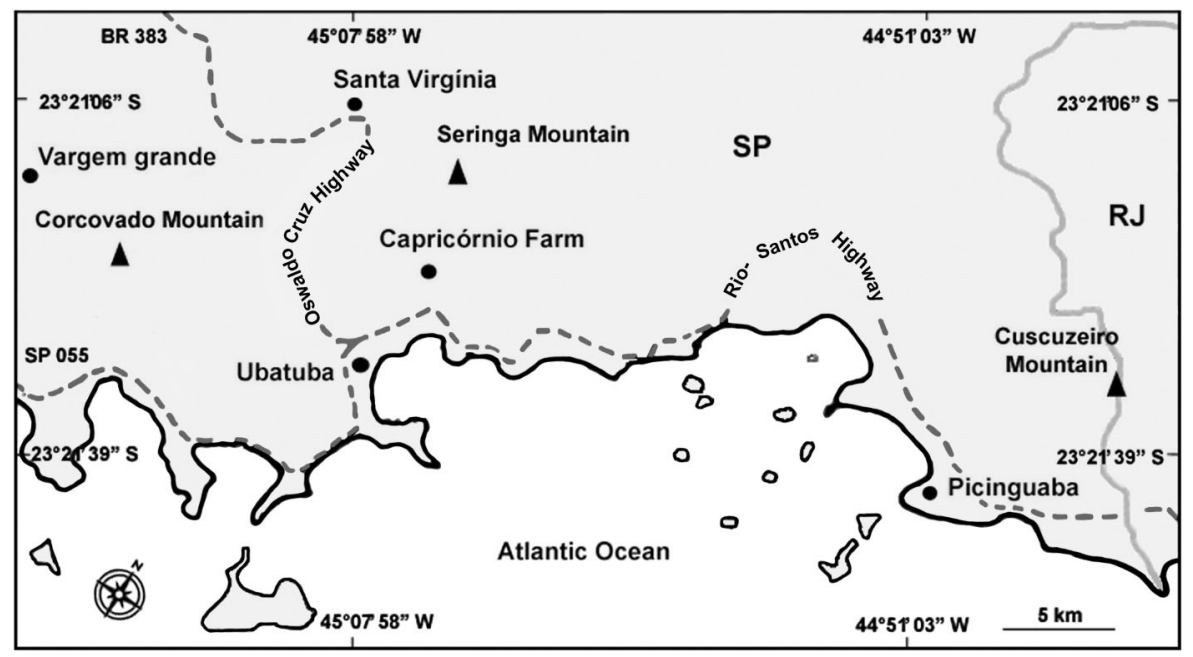

Figure 1. Location of the study area in Picinguaba and Santa Virgínia Nucleus, Serra do Mar State Park. (adapted from MMA/IBGE 2004, SOS Mata Atlântica/INPE 2010, MMA 2012).

also occurs. The climate in Picinguaba is tropical humid (Setzer 1966), with no dry season, with average annual precipitation exceeding $2,200 \mathrm{~mm}$. The soils, in a study conducted by Lacerda (2001) on the coastal plain up to $1,000 \mathrm{~m}$ altitude, showed up acid, poor in nutrients, with high levels of aluminum and organic matter and low fertility.

In the surrounding areas of the Picinguaba Nucleus collections were carried out at altitudes that range from the Restinga Forest, near the sea level up to the vegetation at the top of Cuscuzeiro Mountain at 1,279 m altitude (Figure 1). The areas near the south-central base comprise the ones located at altitudes ranging from $25 \mathrm{~m}$ near the Capricórnio Farm to the top of the Seringa Mountain at 1,090 m altitude. In Santa Virgínia Nucleus collections were also carried out in two areas of the Ombrophilous Dense Forest. The first, located near the headquarter of the nucleus at altitudes which vary from 850$1,100 \mathrm{~m}$, and the second near the Vargem Grande headquarter from $819 \mathrm{~m}$ altitude up to the vegetation at the top of Corcovado Mountain at 1,168 m altitude. Collections along highway Oswaldo Cruz, which connects the city of Ubatuba to the head office in Santa Virgínia Nucleus at the top of Serra do Mar were also carried out. The weather in the region of Santa Virgínia is tropical temperate (Setzer 1966) with no dry season, with average annual precipitation greater than $2,000 \mathrm{~mm}$.

The floristic survey involved the collection of shrubs (including vine), trees and lianas. Herbaceous plants were not found. The classification as for the habit followed the model proposed by Whittaker (1975). The trips to the study area were taken monthly between 2006 and 2009 going through trails in different vegetation types. All material collected is incorporated into the collection of the UEC Herbarium. Voucher material was selected and the name and number of the collector, followed by the herbarium acronym, was inserted after the name of the species (Table 1). The terminology used to indicate the native, alien or naturalized species is the one proposed by Pysek et al. (2004). Information concerning the origin of these taxa were obtained in the List of Species of Brazilian Flora (2015). In the same table, codes were inserted concerning the environment in which each species was found in the study area (native forest, anthropized forest or both). The final list was complemented with other botanists collections previously conducted in the study area and deposited in herbaria. The identification of specimens was based on literature consultation and on the comparison of materials deposited in the herbaria in São Paulo state (UEC, SP, SPF, ESA and HRCB, which acquis has the Flórula Picinguaba collection) in herbaria from other states (HB, MBM, R and RB) and foreign herbaria (US and NY).

Distribution data used in the discussion is the result of the collected information on reviews and theses, herbarium material and geographical distribution sites (ILDS Legume Database 2012, Species link 2013 and List of Species of Brazilian Flora 2015). To verify the distribuition of taxa of Leguminosae along a gradient, a matrix of presence and absence of species was elaborated and applied to 15 different belts. The altitudinal amplitude of each belt, just after Lowland, is $100 \mathrm{~m}$ and have as its main objective to find out the extent of altitudinal variation of each specie along the phytophysiognomies. The data relating to location and altitude was obtained through the use of GPS. In some cases, when the altitude reading by the GPS was impossible, estimates from known points were made. These phytophysiognomies were adapted from the classification system proposed by Veloso et al. (1991) and adopted by IBGE (Brazilian Institute of Geography and Statistics), recently updated et IBGE 2012, in which the Ombrophilous Dense Forest, in the domain area of the Atlantic Forest, has been subdivided into four zones ordered according to the latitudinal and altimetric variations. The Restinga-Lowland transition, which occurs up to five meters in the IBGE system, was extended to 10 meters in this study as we observed that many known species of Restinga occur beyond five meters.

To study the distribution of species along the altitudinal gradient, cluster analysis and ordination with all tree species were conducted. With a matrix of presence and absence of each specie per altitudinal belts a similarity matrix between altitudinal belts using the Jaccard index was calculated. It was used the hierarchical clustering method - UPGMA to produce a dendrogram with the similarity matrix to verify if the forest formations would form well established groups. To check for substitution of species along the altitudinal belts we carried out a correspondence analysis (CA). An analysis using 


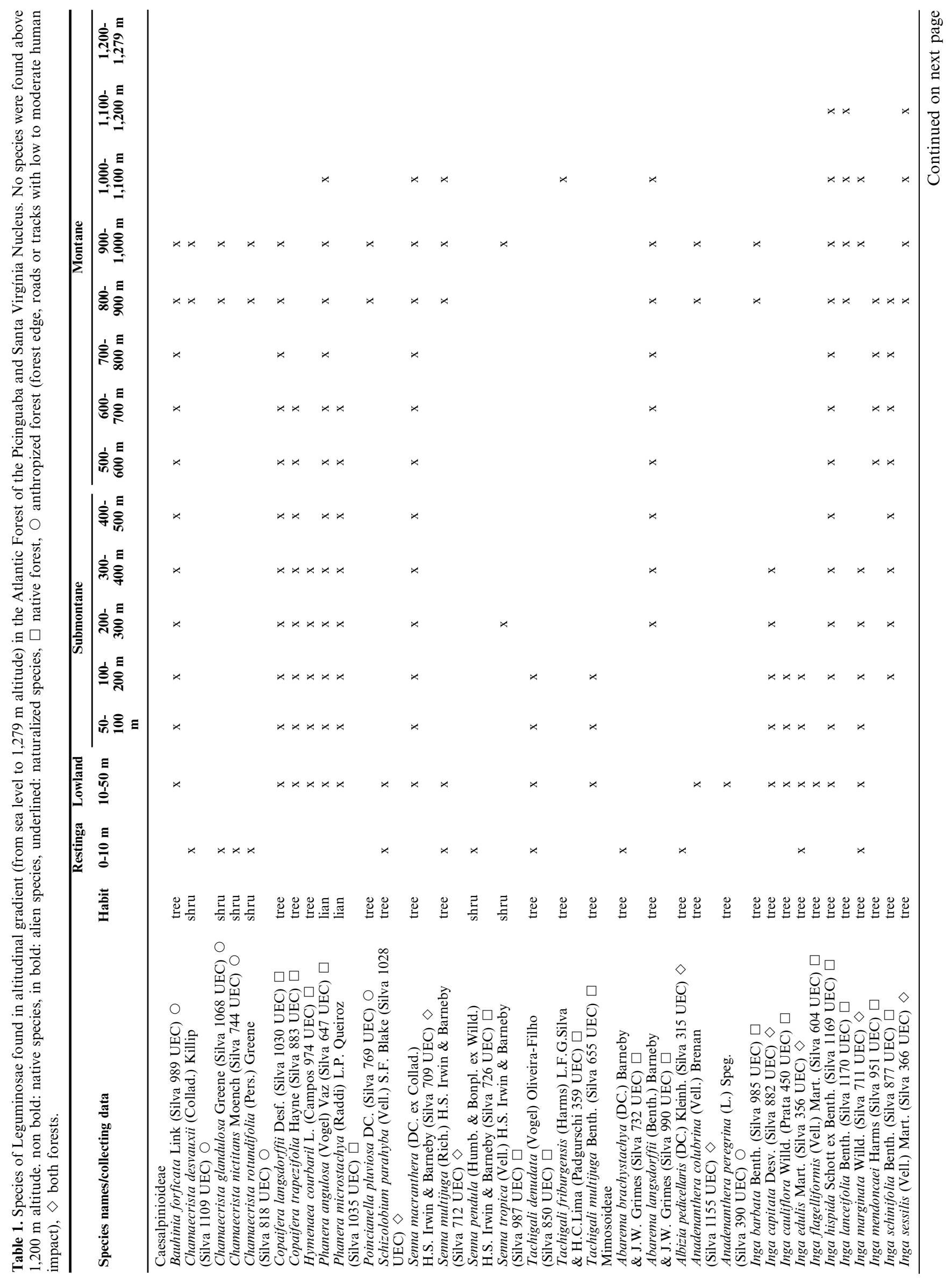




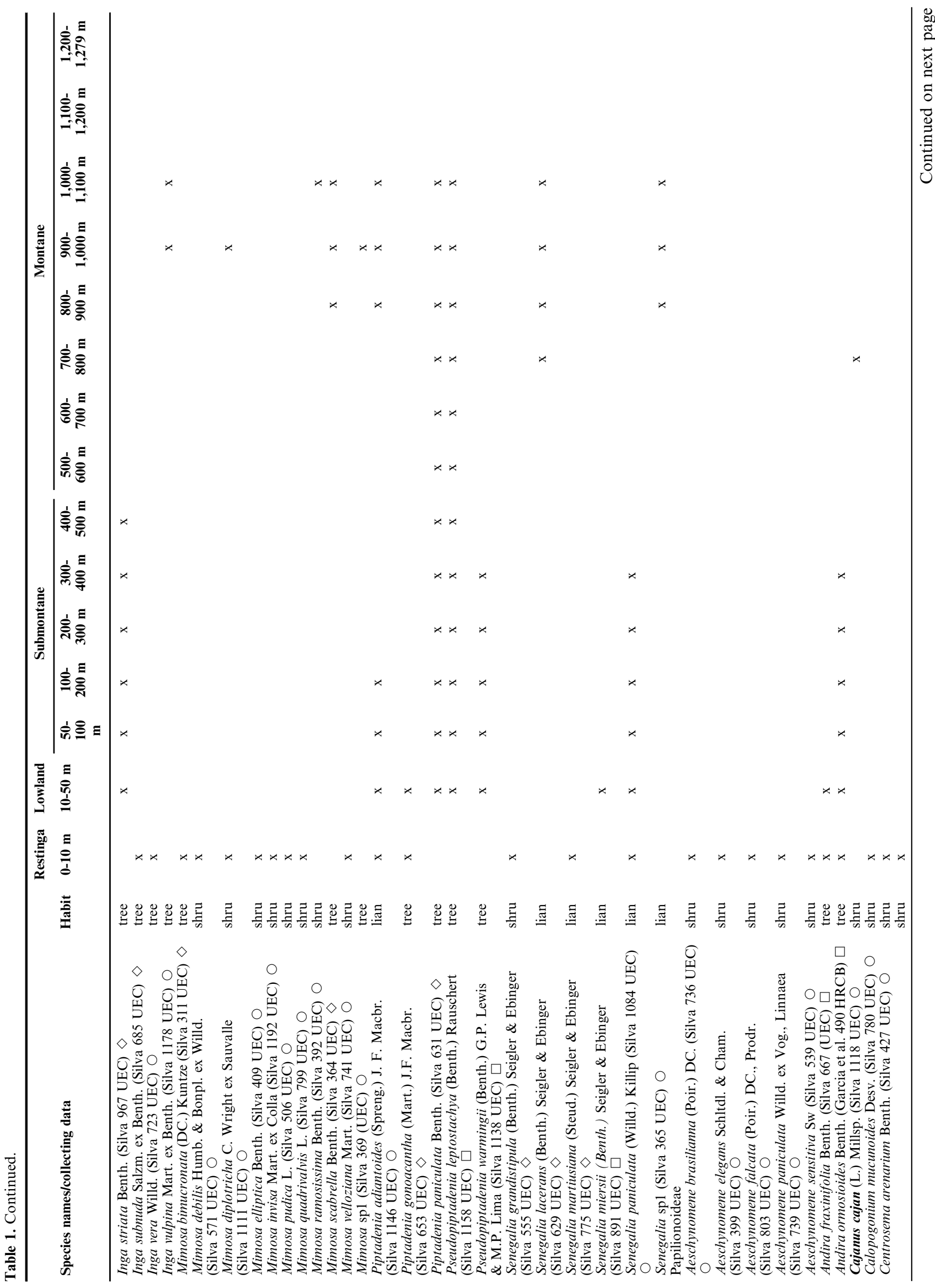




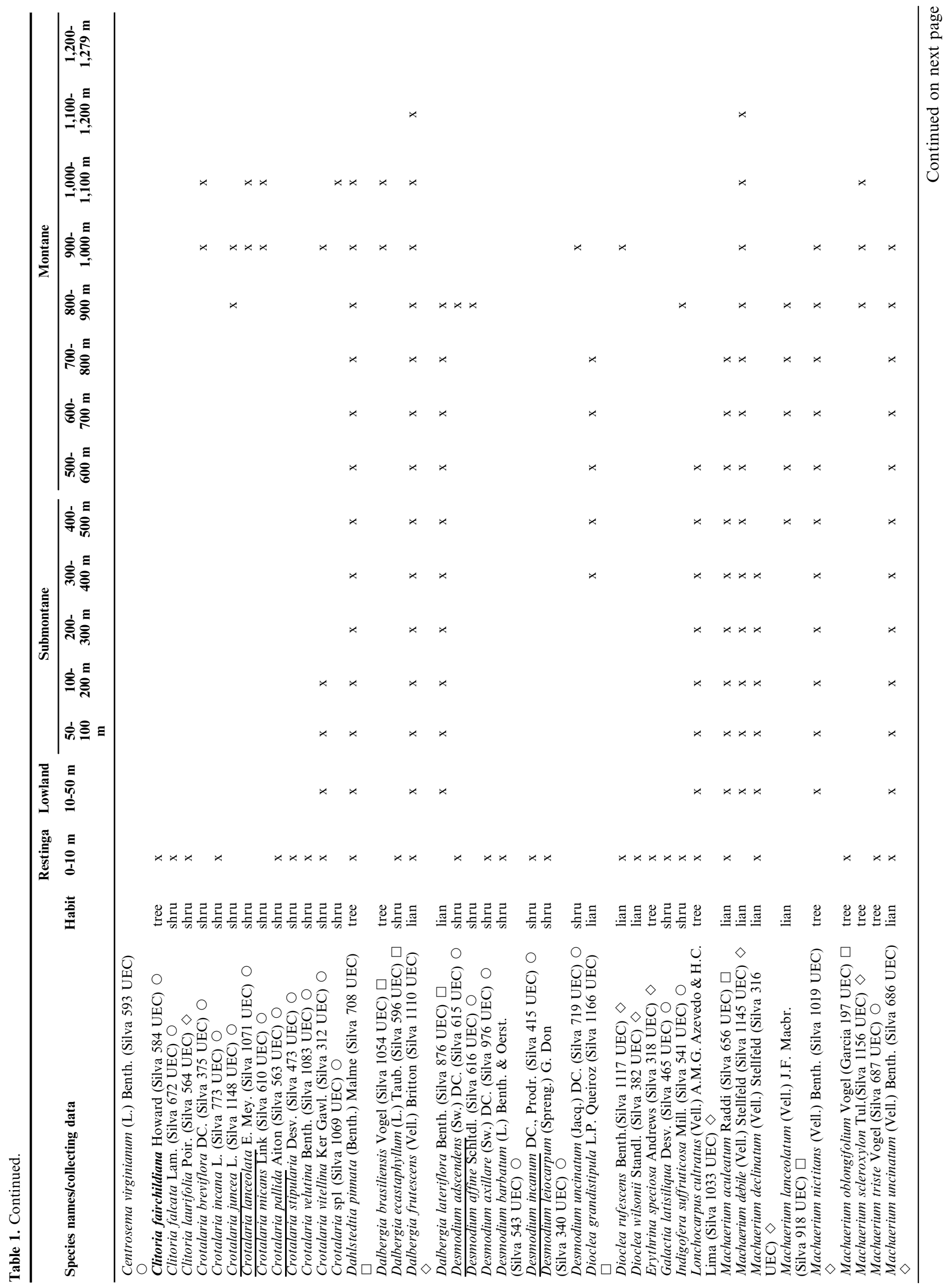




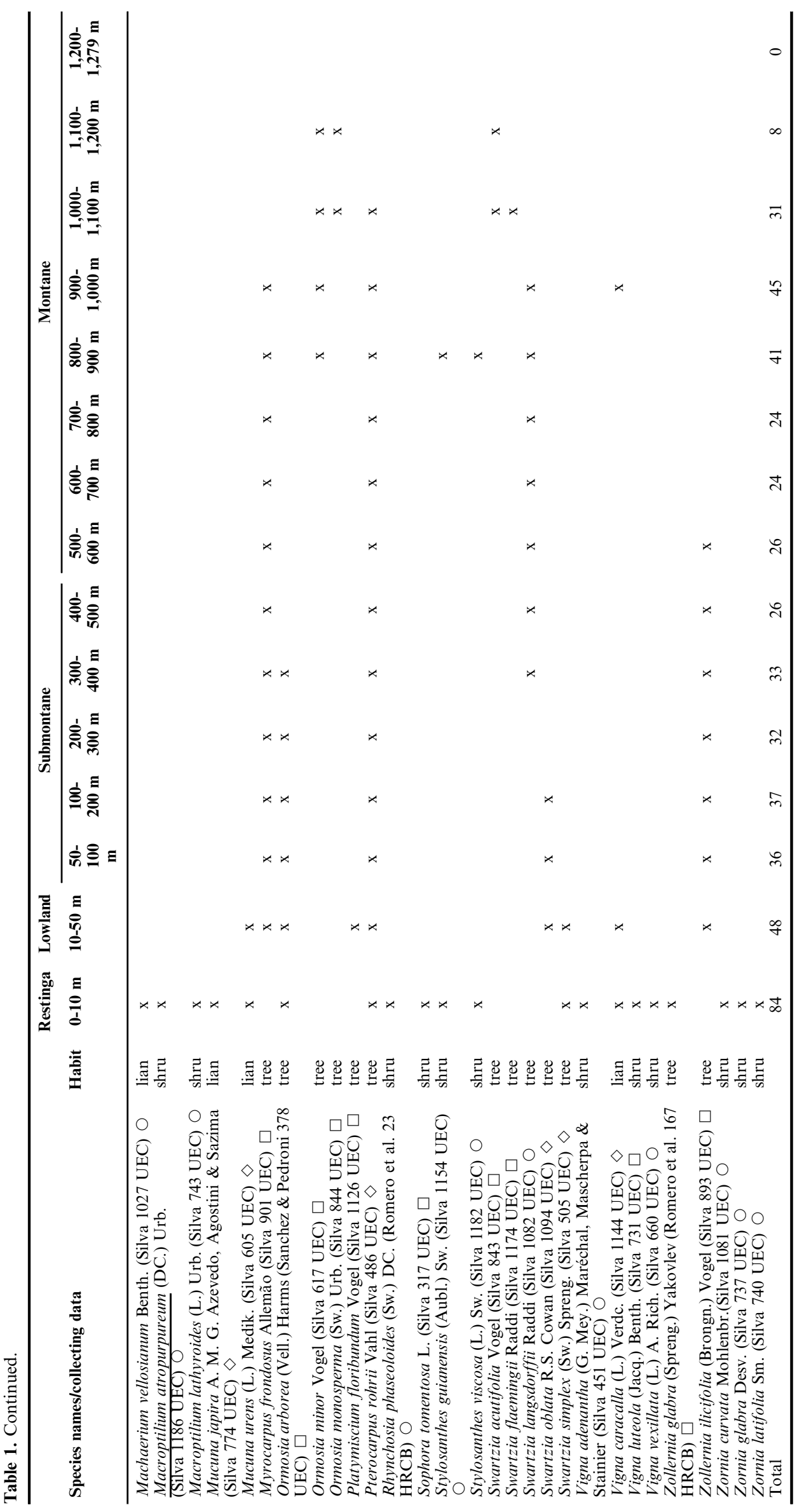


divisive clustering - TWINSPAN was carried out with the tree species to verify which species could be indicators of these forest formations. These analyses were performed using Fitopac 1.6.4 program (Shepherd 2006).

\section{Results}

A total of 142 species of Leguminosae belonging to 45 genera were found in the studied altitudinal gradient $(0-1,279 \mathrm{~m})$, being 62 trees, 58 shrubs and 22 lianas (Table 1). No species were found above 1,200 $\mathrm{m}$ of altitude. The Papilionoideae subfamily showed higher species richness (81 spp), followed by Mimosoideae with 42 species (Table 1). Considering the tree species only, Mimosoideae appears with the greatest number of species being the best represented group inside the Forest.

Restinga Forest showed higher species richness (84), being 23 trees, 48 shrubs and 13 lianas. From the total of species, 52 were exclusive to Restinga Forest (Table 2). The Montane Forest was the second formation greater in number of species (69, being 25 exclusive). It is noteworthy that the high number of species found in Montane Forest is due to the presence of shrubs and even lianas that grow in open areas. In the Lowland Forest, 48 species were found, being 3 exclusive. The phytophysiognomy with the lowest number of species was the Submontane Forest, where 43 species were found, it was not registered the presence of any exclusive species. The absence of exclusive species in the Submontane Forest may be associated to the fact that, in general, these species also occur below the established quota for this phytophysiognomy in the Lowland, or immediately above, in Montane Forest. It is worth considering that, despite the fact that the Montane Forest appears second in total number of species, the Leguminosae family is best represented in this phytophysiognomy only from $800-1,000 \mathrm{~m}$ altitude. There is a clear decrease in the number of species in the higher quotas of this formation, from 1,000-1,279 m (Table 1).

The analysis of the distribution of the habits of Leguminosae species in relation to altitude (Figure 2) revealed a higher richness tree species in the quota that represents the Lowland $(10-50 \mathrm{~m})$ with 34 species. The shrubs were more abundant in the Restinga Forest (48 spp.), completely disappearing from 300 to 700 returning to occur from $800-1,100 \mathrm{~m}$ in open areas. The increase in the number of species in Montane Forest (69 spp.) is mainly due to the reappearance of shrub species, but also due to a significant number of tree species that occur only in those quotas. The number of lianas remained constant in almost all quotas, with a significant reduction between 1,100$1,279 \mathrm{~m}$. The number of species and their respective altitudinal quotas by habits are shown in Table 2 .

Analyzing the occurrence of species of Leguminosae in different altitudes (Table 1), we can see that no specie of the Caesalpinioideae subfamily was found occupying all phytophysiognomies. However, Bauhinia forficata, Copaifera langsdorffii, Copaifera trapezifolia, Phanera angular and Senna macranthera, only are not present at Restinga $(0-10 \mathrm{~m})$ and can be found very often in other formations, mainly between 50 and $1,100 \mathrm{~m}$ altitude. Bauhinia forficata, however, was not found inside the forest, but only at the edge of forests, along roads and highways or in other altered areas. Bauhinia microstachya, frequently found in the Lowland $(10-50 \mathrm{~m})$ and Submontane $(50-500 \mathrm{~m})$, was not found above $700 \mathrm{~m}$. Some Caesalpinioideae characterize certain formations or have their preferred environment located at a specific altitude, as is the case of Schizolobium parahyba, which was only found between 0-100 m, Tachigali denudata and Tachigali multijuga that reach up to $200 \mathrm{~m}$ altitude and Hymenaea courbaril found in Lowland and Submontane Forest (10-500 m).

For the Mimosoideae subfamily, we observed that only two species were found in all phytophysiognomies (Inga marginata and Piptadenia adiantoides). The two species, however, are not equally

Table 2. Number of species, genera, tribes and habits of Leguminosae by phytophysiognomies of the Atlantic Forest in Picinguaba and Santa Virgínia Nucleus.

\begin{tabular}{|c|c|c|c|c|c|c|c|}
\hline & \multirow[b]{2}{*}{ Phytophysiognomies } & \multicolumn{3}{|c|}{ Taxa (exclusive) } & \multicolumn{3}{|c|}{ Habits (exclusive) } \\
\hline & & Species & Genera & Tribes & Tree & Shrubs & Lianas \\
\hline \multirow[t]{5}{*}{ Caesalpinioideae } & Restinga $(0-10 \mathrm{~m})$ & $8(2)$ & $3(0)$ & $2(0)$ & $3(0)$ & $5(0)$ & 0 \\
\hline & Lowland (10-50 m) & $11(0)$ & $6(0)$ & $4(0)$ & $9(0)$ & 0 & $2(0)$ \\
\hline & Submontane $(50-500 \mathrm{~m})$ & $10(0)$ & $5(0)$ & $4(0)$ & $7(0)$ & $1(0)$ & $2(0)$ \\
\hline & Montane $(500-1,200 \mathrm{~m})$ & $14(2)$ & $7(1)$ & $4(0)$ & $8(2)$ & $4(0)$ & $2(0)$ \\
\hline & total & 19 & 8 & 4 & 11 & 6 & 2 \\
\hline \multirow[t]{5}{*}{ Mimosoideae } & Restinga $(0-10 \mathrm{~m})$ & $19(13)$ & $6(1)$ & $3(0)$ & $8(5)$ & $8(7)$ & $3(0)$ \\
\hline & Lowland (10-50 m) & $16(2)$ & $5(0)$ & $3(0)$ & $13(2)$ & 0 & $3(0)$ \\
\hline & Submontane $(50-500 \mathrm{~m})$ & $13(0)$ & $5(0)$ & $3(0)$ & $11(0)$ & 0 & $2(0)$ \\
\hline & Montane $(500-1,200 \mathrm{~m})$ & $19(10)$ & $7(0)$ & $3(0)$ & $14(7)$ & $2(1)$ & $3(1)$ \\
\hline & total & 42 & 8 & 3 & 27 & 9 & 6 \\
\hline \multirow[t]{5}{*}{ Papilionoideae } & Restinga (0-10 m) & $57(37)$ & $26(10)$ & $8(0)$ & $12(5)$ & $35(29)$ & $10(3)$ \\
\hline & Lowland (10-50 m) & $21(1)$ & $14(1)$ & $6(0)$ & $12(1)$ & $1(0)$ & $8(0)$ \\
\hline & Submontane $(50-500 \mathrm{~m})$ & $20(0)$ & $12(0)$ & $6(0)$ & $11(0)$ & $1(0)$ & $8(0)$ \\
\hline & Montane $(500-1,200 \mathrm{~m})$ & $36(13)$ & $16(1)$ & $8(0)$ & $13(5)$ & $14(4)$ & $9(1)$ \\
\hline & total & 81 & 29 & 8 & 24 & 43 & 15 \\
\hline \multirow[t]{4}{*}{ Leguminosae } & Restinga $(0-10 \mathrm{~m})$ & $84(52)$ & $35(1)$ & $13(0)$ & $23(10)$ & $48(35)$ & $13(3)$ \\
\hline & Lowland (10-50 m) & $48(3)$ & $25(1)$ & $13(0)$ & $34(3)$ & $1(0)$ & $13(0)$ \\
\hline & Submontane $(50-500 \mathrm{~m})$ & $43(0)$ & $22(0)$ & $13(0)$ & $29(0)$ & $2(0)$ & $12(0)$ \\
\hline & Montane $(500-1,200 \mathrm{~m})$ & $69(25)$ & $30(2)$ & $15(0)$ & $35(14)$ & $20(5)$ & $14(2)$ \\
\hline Total & 142 & 45 & 15 & 62 & 58 & 23 & \\
\hline
\end{tabular}




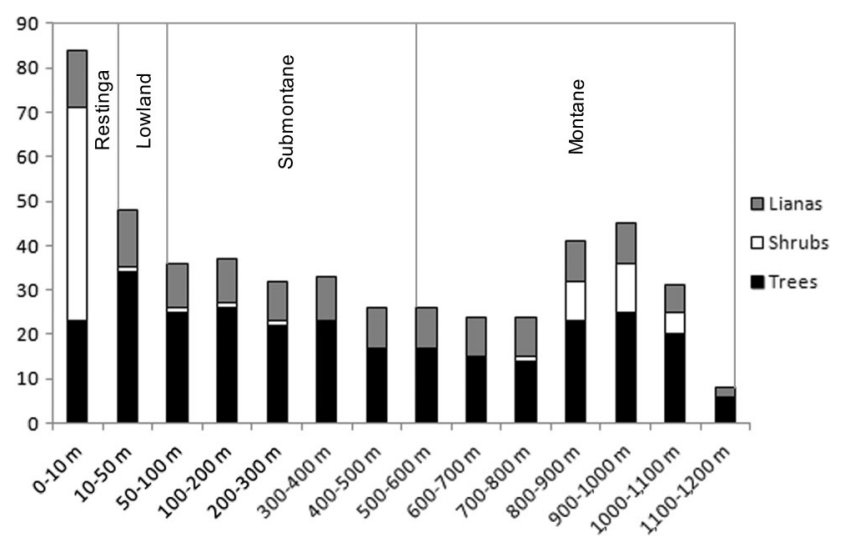

Figure 2. Distribution of habits of Leguminosae species in relation to altitude in Atlantic Forest of Serra do Mar State Park.

distributed, since $P$. adiantoides occurs almost continuously throughout the gradient, while I. marginata is present in abundance only within the Restinga and Lowland Forest, being little found in the Submontane and Montane Forest, where it was found only in open areas, along rivers and forest edges. Thirteen species were found only in the Restinga Forest (Table 2), standing out Abarema brachystachya, Balizia pedicellaris and Inga subnuda that were found most frequently. Also well represented in Restinga, extending to the Lowland, were found Inga edulis and Piptadenia gonoacantha; from Restinga to Submontane (Inga striata, Pseudopiptadenia warmingii and Senegalia paniculata) and from the Lowland to Montane (Inga hispida and Pseudopiptadenia leptostachya). In the Montane Forest, 10 exclusive species were found, occurring more precisely from 700 to $1,100 \mathrm{~m}$ (Inga barbata, Inga lanceifolia, Inga mendoncaei, Inga sessilis, Inga vulpina, Mimosa ramosissima, Mimosa scabrella, Mimosa sp1, Senegalia lacerans and Senegalia sp1). At that altitude we highlight the presence of Inga lanceifolia and Inga sessilis by the large number of individuals inside the forest. It is also important to emphasize the presence of Abarema langsdorffii that although also present in the Submontane
Forest, is very well represented in Montane as well as Inga hispida and Pseudopiptadenia leptostachya, species that are not exclusive to Montane, but are well represented in number of individuals in this phytophysiognomy.

Six species of Papilionoideae were found in all phytophysiognomies, from the sea level to about $1,000 \mathrm{~m}$. Four are lianas (Dalbergia frutescens, Machaerium aculeatum, Machaerium dimorphandrum and Machaerium uncinatum) and two are trees (Dahlstedtia pinnata and Pterocarpus rohrii). All these species grow inside the forest, where they are well represented in number of individuals, or on forest edges and areas where the forest is reestablishing. In Restinga Forest, 37 exclusive species were found (Table 2). Abundant in the Restinga Forest, but extending to the Lowland, include: Andira fraxinifolia, Mucuna urens, Platymiscium floribundum and Swartzia simplex. Six species are present from the Restinga to the Submontane Forest, one of them occurring up to $200 \mathrm{~m}$ (Swartzia oblata) and the remaining from the sea level to about $500 \mathrm{~m}$ altitude (Andira ormosioides, Lonchocarpus cultratus, Machaerium declinatum, Ormosia arborea and Zollernia ilicifolia). In the Montane Forest, 13 species were found. The species of Dalbergia brasiliensis, Machaerium scleroxylon, Ormosia minor, Ormosia monosperma, Swartzia acutifolia and Swartzia flaemingii stand out for occurring only in this formation mainly above $800 \mathrm{~m}$ altitude. Standing out by the large number of individuals, found between 900 and $1,000 \mathrm{~m}$, are the species of Machaerium scleroxylon and Ormosia minor, and by its rarity, the specie of Swartzia flaemingii found just above this quota.

Cluster analysis (UPGMA), which included here only tree species of Leguminosae, revealed some relations for the sample units (phytophysiognomies), highlighting the dissimilarity between the Restinga Forest $(0-10 \mathrm{~m})$ and Montane Forest $(1,100-1,200 \mathrm{~m})$ in relation to the others (Figure 3). At least three distinct groups showed greater similarity between quotas, one of 10-400 m, which corresponds to the Lowland + Submontane; another 400-800 m which encompasses the Submontane + Montane Forest, and another of 800-1,100 $\mathrm{m}$, which corresponds to Montane. The lower altitude quotas of Montane Forest (600-800 m) showed greater similarity with

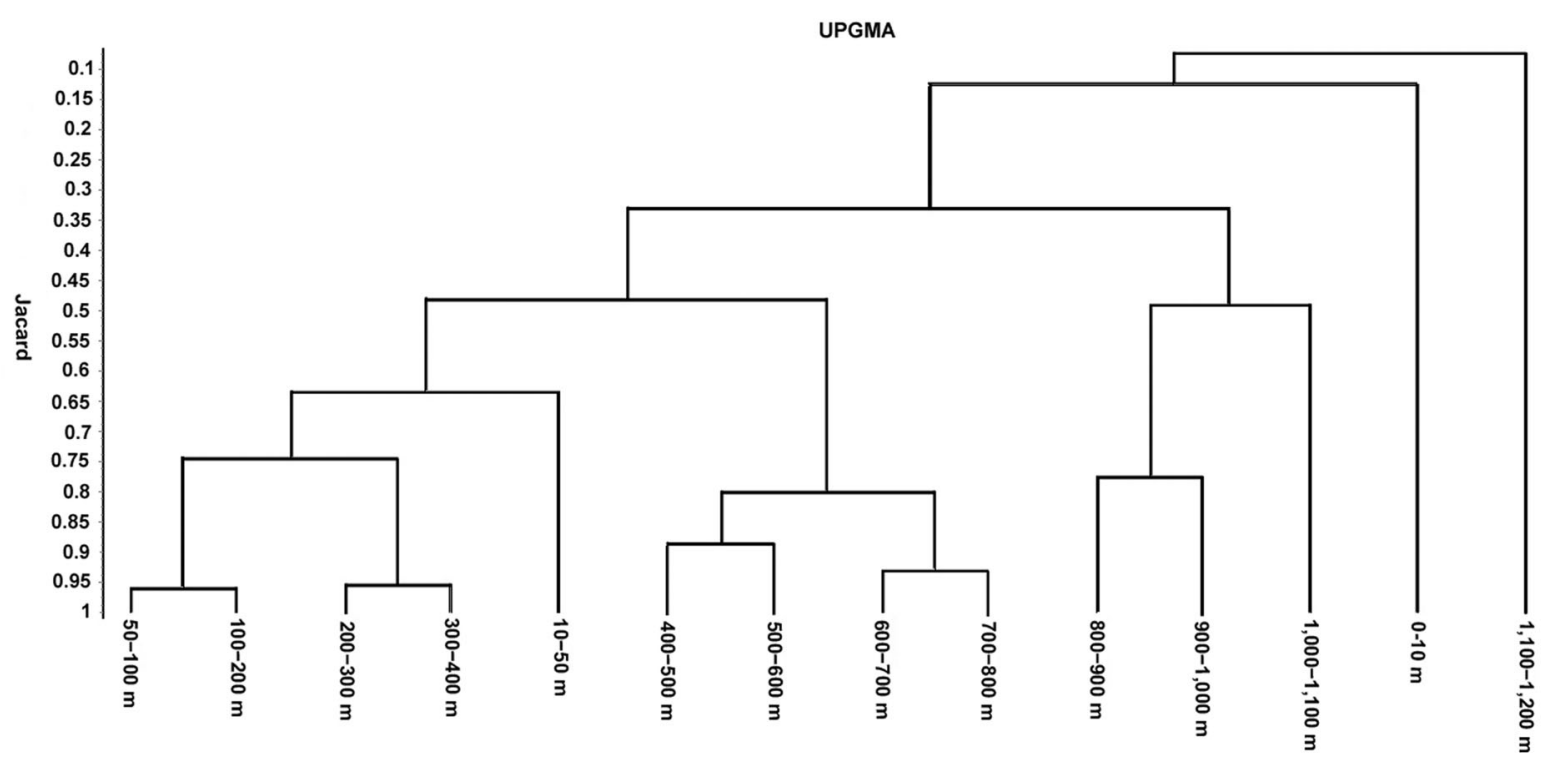

Figure 3. Similarity analysis among different altitudes in Atlantic Forest of Serra do Mar State Park using Jaccard index with Group Average Clustering (UPGMA). Only tree species. 
Silva, E.D. et al.

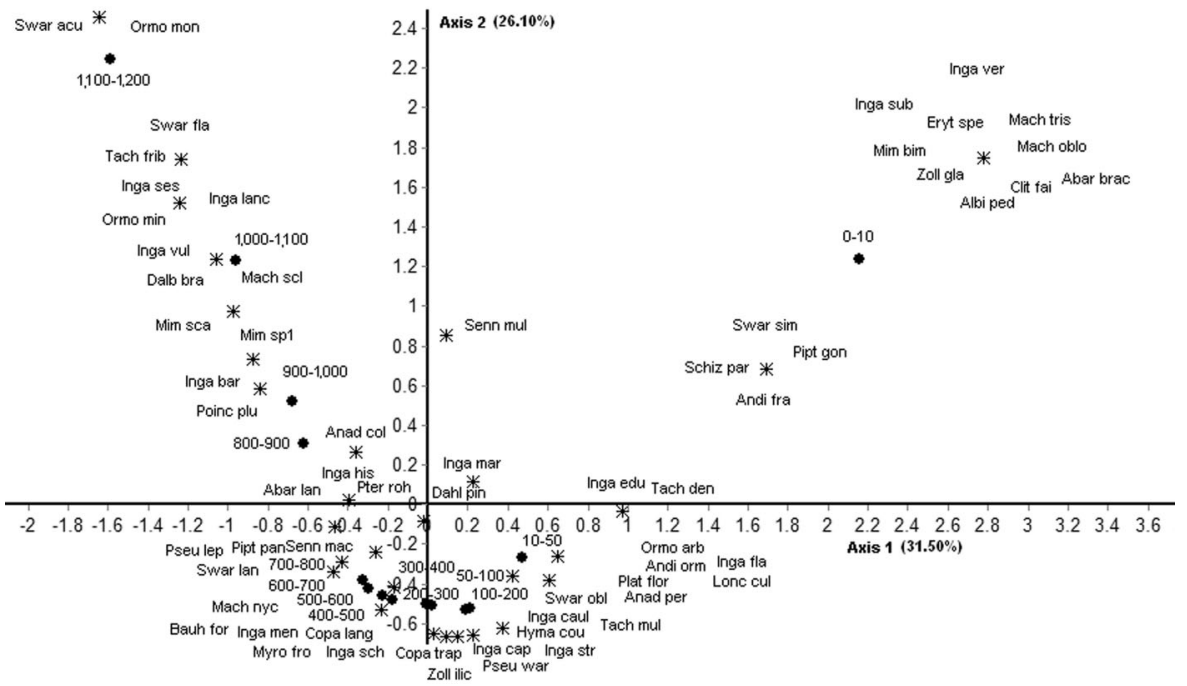

Figure 4. Ordination analyses among different altitudes in Atlantic Forest of Serra do Mar State Park using Correspondence Analysis (CA). Only tree species.

higher quotas of Submontane (400-500 m) than with the higher altitudinal quotas. This can be happening due to a restricted set of species restricted to higher altitudes of Montane Forest.

Correspondence analysis (CA) of the tree species (Figure 4) suggested a high turnover of species along the gradient, with $51.6 \%$ of inertia. The analysis also showed that there is greater similarity between the higher quotas of Montane Forest (800$1,000 \mathrm{~m})$ and that the lower quotas of this formation $(600-800$ $\mathrm{m})$ are more related to those higher of Submontane (400-500 m) as evidenced in the previous analysis (UPGMA).

The largest share of species (Figure 5) occurred between Lowland Forest and Submontane (25 spp.) and the lowest between the Restinga Forest and Montane Forest ( 5 spp.).

The TWINSPAN showed a similar grouping to that obtained by UPGMA. In the first division there was a separation of altitudes quotas of $800-1,200 \mathrm{~m}$ (Montane Forest) from the remaining quotas being Inga lanceifolia, Inga sessilis and

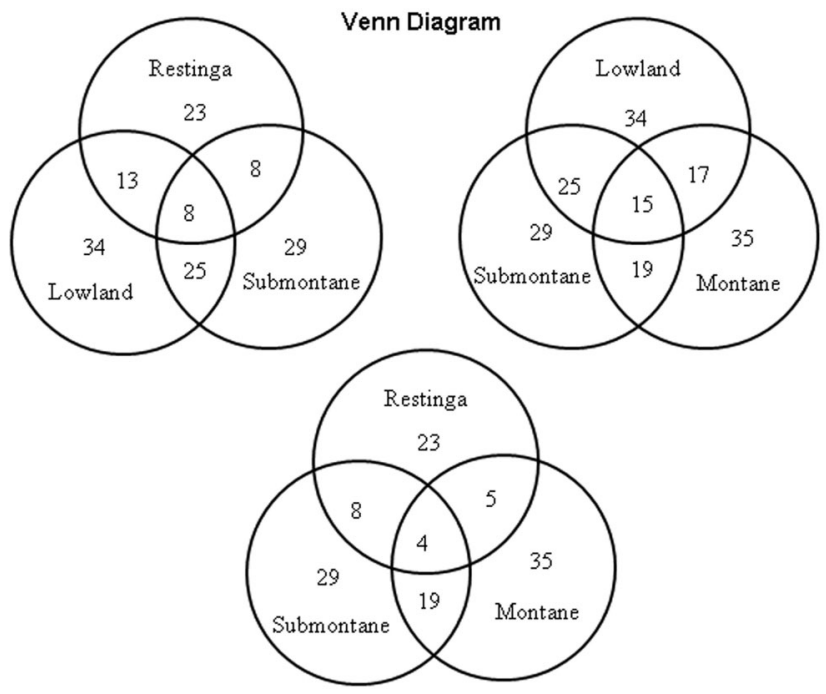

Figure 5. Sharing of species among phytophysiognomies in Atlantic Forest of Serra do Mar State Park using Venn Diagram. Only tree species.
Ormosia minor species indicated for this track separation (eigenvalue 0.520). The second division separated the Restinga Forest from other quotas of 10-800 m, with an eigenvalue of 0.501, being Abarema brachystachya, Inga subnuda and Inga vera, indicated species for this separation. A third division of low eigenvalue was also obtained in Lowland and in the beginning of the Submontane Forest, with different groups of 10 to $200 \mathrm{~m}$ (Inga cauliflora, Inga edulis, Swartzia oblate, Tachigali denudata, Tachigali multijuga) and 200-800 m (Abarema langsdorffii, Inga mendoncaei, Inga schinifolia, Swartzia langsdorffii).

\section{Discussion}

Among the vegetation types that comprise the Atlantic Forest domain on the northern coast of São Paulo, the Restinga Forest has been the poorest in numbers of tree species, especially when compared to the Lowland (Lacerda 2001, Assis et al. 2011). Specifically for the Leguminosae family, this trend was also observed in the study area, with 34 tree species present in the Lowland and only 23 in Restinga (Table 2). The physicochemical differences of soil, temperature and precipitation have been identified as the main causes of lower tree species richness in Restinga. Lacerda (2001) suggests that, in the plain, different patterns of precipitation and temperature, the water excess, during periods of upwelling of groundwater, and consequent salinity salt spray carried by breezes and deposited in the soil by rain are factors that can be limiting the establishment of many slope species at Restinga. Despite the lower tree species richness in Restinga, some species are well represented in number of individuals on this formation. In a survey conducted in a block of 1 ha $(100 \times 100 \mathrm{~m})$ in Restinga in Picinguaba (Assis et al. 2011), which included trees with diameter at breast height $\geq 4.8$ $\mathrm{cm}, 22$ individuals of the Andira fraxinifolia and 29 of Inga subnuda were found.

This formation, however, is richer than the Lowland when considering all the habits of the Leguminosae family. Some species of shrubs seem well adapted to the environmental conditions present in Restinga, as they also occur in other areas of such formation in São Paulo coast, as Dalbergia ecastaphyllum, Senna pendula, Sophora tomentosa and Vigna luteola. Data 
Leguminosae in Atlantic Forest of Serra do Mar




comparing the species richness of the Lowland with the other formations are scarce and hampered by differences in the methodology used in the studies.

Phytosociological studies carried out in altitudinal gradients in Serra do Mar (Roderjan 1994, Lacerda 2001, Custodio Filho 2002, Bertoncello 2009) have shown that species richness decreases at higher altitudes. To Leguminosae, however, the data from these studies show that the percentual of species is very similar up to $1,000 \mathrm{~m}$ altitude and only decreases considerably after this quota (Table 3), except for the differences that hinder comparisons between areas, such as the methodology used in the study, size of the sample area, preserving levels of each area, difficult access to collection sites, delimitation of the parameters to include the individual in the sample.

In the study area, excluding the Restinga Forest $(0-10 \mathrm{~m})$, which is a distinctive vegetation type, we realize that up to $1,000 \mathrm{~m}$ the tree species of the Leguminosae family is very similar, taking into account the full amplitude established for each formation. In the Lowland $(10-50 \mathrm{~m}) 34$ species were found, in the Submontane $(100-500 \mathrm{~m}) 29$ were found and in Montane (500-1,200 m) 35 species occurred (Table 2). It is interesting to note that this similar number is maintained by different species and more evident when we look at the distribution by belt (Table 1). It seems, therefore, to occur species replacement along the gradient as shown in CA analysis. Legume species would then be occupying specific altitudinal zones within the forest. Genera well represented in our sample such as Inga, Machaerium and Swartzia, are present throughout the whole gradient by species that are occupying different altitudes. Many species of Leguminosae, therefore, characterize certain formations or have their preferred environment located at a specific altitude and thus being species indicator of phytophysiognomies.

The analysis of data by established quota shows that there are differences in the number of tree species, being the belt of transition between the plain and the slope represented by Lowland Forest (10-50 m), the richest in number of species (34) and the belt of $1,100-1,200 \mathrm{~m}$, which is Montane Forest, the one that has the lowest number of species (6) showing the most commonly observed tendency in studies involving the distribution of species in altitudinal gradients.

The distribution of Leguminosae species at different altitudes may be related to environmental variables such as nutrient availability and soil depth, luminosity, temperature, precipitation and humidity. The interaction between increased precipitation and the decreasing of temperature with altitude has been associated with the reducing on the number of species in altitudinal gradients (Gentry 1982, Richards 1996, Gentry 1988). The decreasing of temperature with altitude may also be influencing a decrease in the rates of decomposition of organic matter preventing some nutrients from being returned to the soil. Ashton (1977) and Gartlan et al. (1986) suggested that phosphorus, magnesium and potassium are among the nutrients which levels are more related to diversity in the tropic plant community. To Grubb (1977), the slow rate of decomposition caused by the decrease in temperature at higher altitudes makes the soils of montane forests poor in nitrogen and phosphorus.

These variables would be exerting a selection of species per altitudinal belts since there are few species of the family that are adapted to a broader range of these environmental variables occurring in all altitudinal groups studied (two Mimosoideae and seven Papilionoideae).
For Lacerda (2001), the decrease of the richness presented above $1,100 \mathrm{~m}$ in Picinguaba can be related to the decrease in temperature and the presence almost daily of haze, which can interfere in other variables such as insolation and air humidity. According to Rambo (1953), the worsening of environmental conditions above $1,000 \mathrm{~m}$ of altitude, mainly due to edaphic and climatic aspects, dramatically affects the forest vegetation. Above this altitude the trees reduce in height and diameter and the vegetation becomes dense with floristic structure extremely impoverished. These formations are common and very similar to all the coastal mountains from the Brazilian southeast, defined by the same author as "matinhas nebulares" for being constantly submitted to dense fogs (Rambo 1953).

In the study area, these and other variables may be influencing the distribution of species of Leguminosae. The fact that no species of Caesalpinioideae have been found occupying all phytophysiognomies, but some of them (Bauhinia forficata, Copaifera langsdorffii, Copaifera trapezifolia, Phanera angulosa and Senna macranthera) are not present only in the Restinga $(0-10 \mathrm{~m})$ and above $1,100 \mathrm{~m}$, may indicate that these two formations would somehow be limiting the development of these species. The absence of Bauhinia microstachya above $700 \mathrm{~m}$, as shown in our results, however, should be viewed with caution, because data in the literature (Vaz 1993) and herbarium material showed that these species may occur up to $1,000 \mathrm{~m}$ altitude. Poincianella pluviosa, which according to Ulibarri (1996), is a specie that occupies areas inside forests, was only found in open areas of the Santa Virgínia Nucleus which may mean that this plant is disappearing from the Atlantic Forest on the north coast of São Paulo. Found only in the Restinga Forest, Senna pendula is a typical specie of this vegetation type as found in herbarium specimens and data from other studies conducted in São Paulo coast (Barros et al. 1991, Mamede et al. 2004).

The Mimosoideae subfamily, by having only two species present throughout the gradient, seems not to respond to different environmental conditions imposed by the different altitudes. In the study area, as elsewhere in the Atlantic Forest in the states of São Paulo, Paraná, Rio de Janeiro and Espírito Santo, Abarema brachystachya, Balizia pedicellaris and Inga subnuda seem well adapted to the Restinga Forest where they are found very often. Nonetheless, Inga subnuda also occurs in the Lowland (Garcia 1998) and Balizia pedicellaris is not restricted to Restinga vegetation, occupying areas of other vegetation types in the "Chapada Diamantina" and the Amazon region (Barneby \& Grimes 1996). As for other species found in the Restinga Forest, there are records that indicate their occurrence in different vegetation types and altitudes, not only in the state of São Paulo, but also in areas of the central plateau in the states of Minas Gerais, Goiás and Bahia. Of the 11 exclusive species of Montane Forest (Table 1), except Senegalia lacerans, in that herbarium material was recorded to occur at lower altitudes $(30 \mathrm{~m})$ and Abarema langsdorffii which can also occur in the Restinga Forest at sea level (Barneby \& Grimes 1996) it can be stated that these species characterize well this formation in Picinguaba and Santa Virgínia. Still on the species that clearly represent the Montane Forest it is also important to clarify that those belonging to the genera Mimosa occur only in open areas, often disturbed.

The number of species of Papilionoideae occurring in all vegetation types ( $6 \mathrm{spp}$.) corroborates the hypothesis that the taxa of this subfamily are more adapted to a wider range of environmental variations in the gradient studied. These species, however, do not occur over 1,000 $\mathrm{m}$ in Montane Forest. The high 
number of exclusive species of Restinga Forest (Table 1) does not necessarily mean an affinity with this vegetation type since most of these species are shrubby, have a wide geographical distribution and occupy different altitudes, among which the species of the genera Vigna (3 spp.), Zornia (3 spp.), Crotalaria (4 spp.), Desmodium (4 spp.) and Aeschynomene (5 spp.) are outstanding. Of the 38 species of Papilionoideae exclusive to Restinga, only five are really restricted to this formation and do not develop into other phytophysiognomies in the Atlantic Forest (Centrosema virginianum, Dalbergia ecastaphyllum, Machaerium vellosianum, Mucuna japira and Sophora tomentosa). Besides these five species, we could say that also characterize the vegetation of Restinga, by the number of individuals present and their occurrence in other areas of the Atlantic Coast (Dioclea wilsonii, Erythrina speciosa and Vigna luteola). Some genera of Papilinoideae contribute significantly to the diversity of the species distributed in the different levels along the gradient, among which are Andira, Dalbergia, Machaerium, Ormosia and Swartzia species, showing a good ability of these taxa to adapt to changes imposed by altitude. The presence of Machaerium and Swartzia in the list of genera with highest number of species in a survey conducted by Oliveira Filho \& Fontes (2000) on the tree flora of 102 areas of Atlantic Forest corroborates the statement that the contribution of these genres for diversity in tropical forests is quite significant.

Regarding habits, shrubby legume species were not found within the forest. The predominance of arboreal habit within the forest was also demonstrated in a study by Guilherme et al. (2004) in Lowland Forest $(86-130 \mathrm{~m})$ in Intervales, São Paulo. In this study, the Leguminosae family contributed with four species (Copaifera trapezifolia, Pseudopiptadenia warmingii, Pterocarpus rohrii, Schizolobium parahyba) of the 12 with the highest importance (VI) in a vertical strata with trees $\geq 26 \mathrm{~m}$ tall. In the vertical strata with plants $\leq 8 \mathrm{~m}$ tall, Leguminosae species were not found, being Arecaceae, Lauraceae, Myrtaceae, Rubiaceae, Monimiaceae the richest families.

For Richards (1996), tropical forests exhibit a vertical stratification. These strata are composed of various species of plants with different occupation capacities resulting from an adaptive response to the different light conditions. Leguminosae probably should not be adapted to the low incidence of lighting in the lower strata of the forest. The presence of many species of the family at the edges of forest formations is possibly related to high rates of luminosity present in these areas.

The participation of subfamily Mimosoideae as the best represented in tree species in most altitudes (Table 2) is mainly due to the presence of many species of the genera Inga, neotropical group of expressive representation in Ombrophilous Forests.

The dissimilarity of Restinga Forest (0-10 m) and Montane Forest $(1,100-1,200 \mathrm{~m})$, relative to other phytophysiognomies highlighted in the results of the cluster analysis (Figure 3), can be explained by the large number of species restricted to these vegetation types. The greatest similarity found between the sets 10-400 m (Lowland + Submontane), 400-800 m (Submontane + Montane) and 800-1,100 m (Montane) indicates that closer altitudes share a certain number of species. This sharing, however, does not occur significantly at the extremes of the gradient as evidenced in CA, where the lower altitudes of Montane Forest (600-800 m, for example) showed greater similarity with higher quotas of Submontane (400-500 m) than with the immediately higher $(900-1,000 \mathrm{~m})$, due to a number of restricted species of these higher altitudes. The notable species replacement along the altitudinal gradient, with $51.6 \%$ of inertia shown in CA, suggests that there are other ecological variables influencing the distribution of Leguminosae species in the study area. The largest share of species that occur between Lowland Forest and Submontane, evidenced in the Venn diagram, may be linked to the fact that the Lowland presented higher tree species richness, and part of these species still occur just above the altitude established to this formation and, with increasing altitude, these taxa are gradually being replaced by others. The lowest share observed between the Restinga Forest and Montane was expected, because these phytophysiognomies hold a large number of restricted species.

Although the data presented in this study may add information about the distribution of legumes species in an altitudinal gradient, it is important to note that the richness of species can also change with latitudinal variation, which is a well known ecological pattern. The increase or decrease in temperature towards the lower or higher latitudes may be able to change the vegetation types due to the appearance and disappearance of some species.

The altitudinal limits of the phytophysiognomies that comprise the Atlantic Forest present in the current official Brazilian vegetation classification system (Veloso et al. 1991) should also be seen with reservations. According to Joly et al. (1999), there is an academic debate about the limits of the forest subtypes of the Atlantic Forest complex. For Leguminosae, the boundaries between the lower and upper Montane Forest, in the study area, also indicate that those limits may not be well established. Maybe there are numerous small areas with clear floristic differentiation occurring throughout the whole forest that do not allow a very precise separation of these limits. The separation of the highest part of Montane $(1,100$ $1,200 \mathrm{~m})$, in the study area, seem to coincide with the data obtained by Bertoncello et al. (2011). These authors admit the existence of a different vegetation type in the highest part of Cuscuzeiro Mountain (1,120-1,270 m). This vegetation type, called cloud forests, was also found in the southern region by Rambo (1953) and Klein (1980).

Despite the many efforts made in recent decades to understand how plant species are distributed along the surface of the earth, the almost continental dimensions of some phytogeographic areas make it considerably difficult the obtainment of data that can contribute to this understanding. The study of specific plant groups, conducted in smaller areas, may be a way to make this understanding possible. The biodiversity knowledge, allied to the knowledge of how these organisms are distributed, can be an important tool for the conservation of these environments and the organisms that live in them.

\section{Acknowledgments}

The authors thank São Paulo Research Foundation FAPESP (Project Biota Functional Gradient - 03/12595-7), the Fund to Support Teaching, Research and Extension FAEPEX/UNICAMP for financial support; the management and employees of the Forestry Institute - Picinguaba and Santa Virgínia for hosting and support throughout the research; the administrators and employees of Capricórnio Farm for permission and assistance during the collections; the herbaria 
curators by loans of materials; the two anonymous reviewers for valuable suggestions and corrections

\section{References}

ALMEIDA, F.F.M. \& De CARNEIRO, C.D. 1998. Origem e evolução da Serra do Mar. Rev. Bras. Geocienc. 28(2):135-150.

AMORIM, A.M., JARDIM, J.G., LOPES, M.M.M., FIASCHI, P., BORGES, R.A.X., PERDIZ, R.O. \& THOMAS, W.W. 2009. Angiospermas em remanescentes de floresta montana no sul da Bahia, Brasil. Biota neotrop. 9(3): 313-348. http://www.biotaneotropica.org.br/v9n3/pt/fullpaper?bn02909032009 + pt (last access at 06/01/2014)

ASHTON, P.S. 1977. A contribution of rain forest research to evolutionary theory. Ann. Missouri Bot. Gard. 64: 694-705, http://dx. doi.org/10.2307/2395295.

ASSIS, M.A. 1999. Florística e caracterização das comunidades vegetais da planície costeira de Picinguaba, Ubatuba, SP. Tese de Doutorado. Universidade Estadual de Campinas, Campinas.

ASSIS, A.M., PEREIRA, O.J. \& THOMAZ, L.D. 2004. Fitossociologia de uma floresta de restinga no Parque Estadual Paulo César Vinha, Setiba, município de Guarapari (ES). Rev.bras.bot. 27 (2):349-361.

ASSIS, M.A., PRATA, E.M.B., PEDRONI, F., SANCHEZ, M., EISENLOHR, P.V., MARTINS, F.R., SANTOS, F.A.M., TAMASHIRO, J.Y., ALVES, L.F., VIEIRA, S.A., PICCOLO, M.C., MARTINS, S.C., CAMARGO, P.B., CARMO, J.B., SIMOES, E., MARTINELLI, L.A. \& JOLY, C.A. 2011. Florestas de restinga e de terras baixas na planície costeira do sudeste do Brasil: vegetação e heterogeneidade ambiental. Biota neotrop. 11(2): 82-101. http://www.biotaneotropica.org. br/v11n2/pt/fullpaper?bn02111022011 + pt (last access at 03/02/2014), http://dx.doi.org/10.1590/S1676-06032011000200012.

BARNEBY, R.C. \& GRIMES, J.W. 1996. Silk Tree, Guanacaste, Monkey's Earring: A Generic System for the Synandrous Mimosaceae of the Americas. Part I. Abarema, Albizia, and Allies. New York Bot. Gard. 74(1): 1-192.

BARROS, F.; MELO, M.M.R.F.; CHIEA, S.A.C.; KIRIZAWA, M.; WANDERLY, M.G. \& JUNG-MENDAÇOLLI, S.L. 1991. Flora Fanerogâmica da Ilha do Cardoso: Caracterização geral e lista das espécies ocorrentes. Instituto de Botância, São Paulo. v.1.

BERTONCELLO, R. 2009. A vegetação arbórea em um gradiente altitudinal do Morro do Cuscuzeiro, Ubatuba, São Paulo: uma análise florística, fitossociológica e geográfica. Tese de Mestrado. Universidade Estadual de Campinas, Campinas.

BLUM, C.T. \& RODERJAN, C.V. 2007. Espécies indicadoras em um gradiente da Floresta Ombrófila Densa na Serra da Prata, Paraná, Brasil. Ver. Bras. Biociênc. 5(2): 873-875.

BORÉM, R.A.T. \& OLIVEIRA-FILHO, A.T. 2002. Fitossociologia do estrato arbóreo em uma toposseqüência alterada de mata atlântica, no município de Silva Jardim-RJ, Brasil. Rev. arvore 26 (6): 727-742.

CUSTÓDIO FILHO, A. 2002. A Floresta Ombrófila Densa em diferentes altitudes no Parque Estadual Carlos Botelho, São Paulo, Brasil. Tese de Doutorado. Universidade de São Paulo, São Paulo.

GARCIA, F.C.P. 1998. Relações Sistemáticas e Fitogeografia do Gênero Inga Miller (Leguminosae, Mimosoideae, Ingeae) nas Florestas da Costa Sul e Sudeste do Brasil. Tese de Doutorado, Universidade Estadual Paulista, Rio Claro.

GARTLAN, J.S., NEWBERY, D.M.C., THOMAS, D.W. \& WATERINAN, P.G. 1986. The influence of topography and soil phosphorous on the vegetaion of Korup Forest Reserve, Cameroun. Vegetatio 65: 131-148, http://dx.doi.org/10.1007/BF00044814.

GENTRY, A.H. 1982. Patterns of Neotropical plant species diversity. Evol. Biol. 15: 1-84, http://dx.doi.org/10.1007/978-1-4615-6968-8_1.

GENTRY, A.H. 1995. Patterns of diversity and floristic composition in neotropical montane forests. In Biodiversity and conservation of
Neotropical montane forests (S.P. Churchill, H. Balslev, E. Forero \& J.L. Luteyn, eds.). The New York Botanical Garden, New York, p.103-126.

GENTRY, A.H. 1988. Changes in plant community divertsity and floristic composition on enviromental and geographical gradients. Ann. Missouri Bot. Gard. 75: 1-34, http://dx.doi.org/10.2307/2399464.

GRUBB, P.J. 1977. Control of forest growth and distribuition on wet tropical mountains: with special reference to mineral nutrition. Ann. Rev. Ecolog. Syst. 8: 83-107.

GUILHERME, F.A.G., MORELLATO, L.P.C. \& ASSIS, M.A. 2004. Horizontal and vertical tree community structture in a lowland Atlantic Rain Forest, Southeastern Brazil. Rev. Bras. Bot. 27(4): 725-737, http://dx.doi.org/10.1590/S0100-84042004000400012.

IBGE, 2012. Manual técnico da vegetação brasileira. Manuais técnicos em geociências. IBGE. Rio de Janeiro

ILDS, 2012. International Legume Database \& Information Service. http://www.ilds.org (last access at 23/05/2012)., http://dx.doi.org/ 10.1093/nar/gkv1159.

IPNI, 2013. The international plant names index. www.ipni.org (last access at 15/03/2013)., http://dx.doi.org/10.1186/1471-2105-14-16.

JOLY, C.A., AIDAR, M.P.M., KLINK, C.A., MCGRATH, D.G., MOREIRA, A G, MOUTINHO, P., NEPSTAD, D.C., OLIVEIRA, A.A., POTT, A., RODAL, M.J.N. \& SAMPAIO, E.V.S.B. 1999. Evolution of the Brazilian phytogeography classification systems: implications for biodiversity conservation. Ciênc. Cult. 51: 331-348.

KITAYAMA, K. 1992. An altitudinal transect study of the vegetation on Mount Kinabalu, Borneo. Vegetatio 102: 149-171, http://dx. doi.org/10.1007/BF00044731.

KLEIN, R.M. 1980. Ecologia da flora e vegetação do Vale do Itajaí. Sellowia, 31-32: 9-389.

KRONKA, F.J.N., NALON, M.A., MATSUKUMA, C.K., PAVÃO, M., YWANE, M.S.S., KANASHIRO, M.M., LIMA, L.M.P.R., PIRES, A.S., SHIDA, C.N., FUKUDA, J.C., GUILLAUMON J. R., BARBOSA, O., BARRADAS, A.M.F., BORGO, S.C., MONTEIRO, C.H.B., PONTINHAS, A.A.S., ANDRADE G.G., JOLY, C.A., COUTO, H.T.Z. \& BAITELLO, J.B. 2003. O verde em São Paulo. Pesquisa FAPESP 91: 48-53.

LACERDA, M.S. 2001. Composição florística e estrutura da comunidade arbórea num gradiente altitudinal na Mata Atlântica. Tese de Doutorado. Universidade Estadual de Campinas, Campinas.

LEWIS, G.P., SCHRIRE, B., MACKINDE, B. \& LOCK, M. 2005. Legumes of the world. Royal Botanic Gardens, Kew.

LEWIS, G.P. 1987. Legumes of Bahia. Royal Botanical Gardens, Kew. LIMA, H.C. 2000. Leguminosas arbóreas da Mata Atlântica. Tese de Doutorado. Universidade Federal do Rio de Janeiro, Rio de Janeiro.

LIMA, H.C., FORTUNA-PEREZ, A.P., TOZZI, A.M.G.A., FLORES, A.S., VAZ, A.M.S.F., KLITGAARD, B.B., CARDOSO, D.B.O.S., FILARDI, F.L., GARCIA, F.C.P., LEWIS, G. P., IGANCI, J.R.V., MEIRELES, J.E., VALLS, J.F.M., LIMA, L.C.P., QUEIROZ, L.P., SILVA, M.J., MORIM, M.P., BARROS, M.J.F., QUEIROZ, R.T., FORTUNATO, R.H., PENNINGTON, R.T., MIOTTO, S.T.S., MOURA, T.N., DUTRA, V. F., MANSANO, V., SOUZA, V.C. \& SCALON, V.C. 2009. In Fabaceae-Leguminosae (J.R. Stehmann, R.C. Forzza, A. Salino, M. Sobral, D.P. Costa, L.H.Y. Kamino, Orgs.). Plantas da Floresta Atlântica. Jardim Botânico do Rio de Janeiro, Rio de Janeiro, p.259-283.

LIMA, H.C., QUEIROZ, L.P., MORIM, M.P., SOUZA, V.C., DUTRA, V.F., BORTOLUZZI, R.L.C., IGANCI, J.R.V., FORTUNATO, R.H., VAZ, A.M.S.F., SOUZA, E.R., FILARDI, F.L.R., VALLS, J.F.M., GARCIA, F.C.P., FERNANDES, J.M., MARTINS-DA-SILVA, R.C.V., PEREZ, A.P.F., MANSANO, V.F., MIOTTO, S.T.S., TOZZI, A.M.G.A., MEIRELES, J.E., LIMA, L.C.P., OLIVEIRA, M.L.A.A., FLORES, A.S., TORKE, B.M., PINTO, R.B., LEWIS, G.P., BARROS, M.J.F., SCHÜTZ, R., PENNINGTON, T., KLITGAARD, B.B., RANDO, J.G., SCALON, V.R., CARDOSO, D.B.O.S., COSTA, L.C., SILVA, M.J., MOURA, T.M., BARROS, L.A.V., SILVA, M.C.R., QUEIROZ, 
R.T., SARTORI, A.L.B., CAMARGO, R. 2012. In Fabaceae (R.C. Forzza, J.F. Baumgratz, C.E.M. Bicudo, A. Carvalho-Junior, A. Costa, D.P. Costa, M.J.G. Hopkins, P. Leitman, L.G. Lohmann, L.C. Maia, G. Martinelli, M. Menezes, M.P. Morim, M.N. Coelho, A.L. Peixoto, J.R. Pirani, J. Prado, L.P. Queiroz, V.C. Souza, J. Stehmann, L. Sylvestre, B.M.T. Walter \& D. Zappi. Orgs.). Catálogo das Plantas e Fungos do Brasil. Jardim Botânico do Rio de Janeiro, Rio de Janeiro, 2: 989-1102.

LISTA DE ESPÉCIES DA FLORA DO BRASIL. 2015. Jardim Botânico do Rio de Janeiro. http://floradobrasil.jbrj.gov.br (last access at 7/09/2015).

MAMEDE, M.C.H., CORDEIRO, I., ROSSI, L., MELO, M.M.R.F. \& OLIVEIRA, R.J. 2004. Mata Atlantica. In Estação Ecológica Juréia-Itatins: ambiente físico, flora e fauna (A.O.V. Marques \& W. Duleba, eds.), Holos Editora, Ribeirão Preto, p.115-132.

MEIRELES, L.D. 2009. Estudos florísticos, fitossociológicos e fitogeográficos em formações vegetais altimontanas da serra da mantiqueira meridional, sudeste do Brasil. Tese de Doutorado, Universidade Estadual de Campinas, Campinas.

MMA - MINISTÉRIO DO MEIO AMBIENTE \& IBGE - INSTITUTO BRASILEIRO DE GEOGRAFIA E ESTATÍSTICA, 2004. Mapa de Biomas do Brasil: primeira aproximação. IBGE.

MMA - MINISTÉRIO DO MEIO AMBIENTE. 2012. http://www. mma.gov.br/governanca-ambiental/geoprocessamento (last access at $15 / 03 / 2013$ ).

MYERS, N., MITTERMEIER, R.A, MITTERMEIER, C.G, FONSECA, G.A.B. \& KENT J. 2000. Biodiversity Hotspots for Conservation Priorities. Nature 403: 853-858, http://dx.doi.org/ 10.1038/35002501;

TROPICOS, 2013. MISSOURI BOTANICAL GARDEN. http:// www.tropicos.org (last access at 15/03/2013).

MANTOVANI, W. 1991. Leguminosae. In Flora Fanerogâmica da Ilha do Cardoso: caracterização geral e lista das espécies ocorrentes (F. Barros, M.M.R.F. Melo, S.A.C. Chiea, M. Kirizawa, M.G. Wanderly, S.L. Jung-Mendaçolli, eds.). Instituto de Botância, São Paulo, p.111-117.

MARQUES, M.C.M., Vaz, A.S.F. \& Marquete, R. 1997. Flórula da APA Cairuçu. Parati. Espécies vasculares. Jardim Botânico do Rio de Janeiro. Sér. Estud. e Contrib. 14: 9-576.

MORI, S.A., BOOM, B.M. \& PRANCE, G.T. 1981. Distribuition patterns and conservation of eastern Brazilian coastal forest tree species. Brittonia 33: 233-245, http://dx.doi.org/10.2307/2806330.

OLIVEIRA-FILHO, A.T. \& FONTES, M.A.L. 2000. Patterns of floristic differentiation among Atlantic Forest in southeastern Brazil and the influence of climate. Biotropica 32: 793-810, http:// dx.doi.org/10.1111/j.1744-7429.2000.tb00619.x.

PEIXOTO, G.L., MARTINS, S.V., SILVA, A.F. \& SILVA, E. 2005. Estrutura do componente arbóreo de um trecho de Floresta Atlântica na Área de Proteção Ambiental da Serra da Capoeira Grande, Rio de Janeiro, RJ, Brasil. Acta Bot. Bras. 19(3): 539-547.

PEREIRA, O.J. \& ASSIS, A.M. 2000. Florística da Restinga de Camburi, Vitória, ES. Acta Bot. Bras. 14(1): 99-111, http://dx.doi.org/ 10.1590/S0102-33062000000100009.

PYSEK, P., Richardson, D.M., Rejmánek, M., Webster, G.L., Williamson, M. \& Kirschner, J. 2004. Alien plants in checklists and floras: towards better communication between taxonomists and ecologists. Taxon 53: 131-143, http://dx.doi.org/10.2307/4135498.

RAMBO, B. 1953. História da flora do planalto riograndense. Sellowia 5: $185-232$.

RICHARDS, P.W. 1996. The tropical rains forest: an ecological study. Cambridge University Press, New York.

RIBEIRO, M.C., METZGER, J.C., MARTENSEN, A.C., PONZONI, F.J. \& HIROTA, M.M. 2009. The Brazilian Atlantic
Forest: How much is left, and how is the remaining forest distruted? Implication for conservation. Biol. Conserv. 142: 1141-1153, http://dx.doi.org/10.1016/j.biocon.2009.02.021.

RIZZINI, C.T. 1997. Tratado de Fitogeografia do Brasil: aspectos ecológicos, sociológicos e florísticos. Âmbito Cultural. Rio de Janeiro.

RODRIGUES, R.R. \& SHEPHERD, G.J. 1992. Análise da variação estrutural e fisionômica da vegetação e características edáficas, num gradiente altitudinal na Serra do Japi. In História Natural da Serra do Japi: ecologia e preservação de uma área florestal no sudeste do Brasil (Morellato, L. P. C., coord.). Editora da Universidade de Campinas, Campinas, p. 64-97.

RODERJAN, C.V. 1994. O gradiente da Floresta Ombrófila Densa no morro Anhangava, Quatro Barras, PR - aspectos climáticos, pedológicos e fitossociológicos. Tese de Doutorado. Universidade Federal do Paraná, Paraná., http://dx.doi.org/10.5380/rf.v31i12.9485.

SCHMIDLIN, L.A.J., ACCIOLY, A., ACCIOLY, P. \& KIRCHNER, F.F. 2005. Mapeamento e caracterização de Superagui utilizando técnicas de geoprocessamento. Floresta 35(2): 303-305, http://dx. doi.org/10.5380/rf.v35i2.4618.

SCUDELLER, V.V., MARTINS, F.R. \& SHEPHERD, G.J. 2001. Distribuition and abundance of arboreal species in the atlantic ombrophilous dense forest in Southeastern Brazil. Plant Ecol. 152: 185-199, http://dx.doi.org/10.1023/A:1011494228661.

SETZER, J. 1966. Atlas climatológico do estado de São Paulo. Comissão interestadual da bacia do Paraná- Paraguai. Cesp, São Paulo.

SHEPHERD, G.J. 2006. FITOPAC 1.6. manual do usuário. Departamento de Botânica da Universidade Estadual de Campinas, Campinas.

SILVA, S.M. 1998. As formações vegetais da planície litorânea da Ilha do Mel, Paraná, Brasil: composição florística e principais características estruturais. Tese de Doutorado, Universidade Estadual de Campinas, Campinas.

SOS MATA ATLÂNTICA \& INPE - INSTITUTO NACIONAL DE PESQUISAS ESPACIAIS, 2010. Atlas dos remanescentes florestais da Mata Atlântica período 2008-2010. Arcplan, São Paulo.

SPECIES LINK, 2013. Centro de Referência em Informação Ambiental \& Fundação de Amparo à Pesquisa do Estado de São Paulo. http://www.splink.cria.org.br (last access 06/08/2013).

SUGUIO, O.K. \& TESSLER, M.G. 1984. Planícies de cordões litorâneos quaternários do Brasil: origem e nomenclatura. In: Lacerda LD, Araújo DSD, Cerqueira R, Turcq B. eds. Restingas: origem estruturas e processos. Niterói: CEUFF. 195-216.

TABARELLI, M. \& MANTOVANI, W. 1999. A riqueza de espécies arbóreas na Floresta Atlântica de encosta no estado de São Paulo (Brasil). Ver. Bras. Bot. 22(2): 217-223.

ULIBARRI, E.A. 1996. Sinopsis de Caesalpinia y Hoffmannseggia (Leguminosae-Caesalpinioideae) de Sudamérica. Darwiniana 34: 299-344.

VASQUEZ, G.J.A. \& GIVNISH, T.J. 1998. Altitudinal gradients in tropical forest composition, structure and diversity in the Siera de Manantlán. J. Ecol. 86: 999-1020, http://dx.doi.org/10.1046/j.13652745.1998.00325.x.

VAZ, A.M.S.F. 1993. Trepadeiras do gênero Bauhinia (Caesalpiniaceae). Pesqui. Bot. 44: 95-114.

VELOSO, H.P., RANGEL-FILHO, A.L.R. \& LIMA, J.C.A. 1991. Classificação da vegetação brasileira adaptada a um sistema universal. IBGE, Rio de Janeiro.

WHITMORE, T.C. 1984. Tropical rain forest of the far east. Claredon Press, Oxford.

WITTAKER, R.H. 1975. Communities and ecosystems. Macmillan, New York 